\title{
Penentuan Debit Aliran di Muara Sungai Pawan Kabupaten Ketapang berdasarkan Parameter Kecepatan Arus dan Kedalaman Sungai
}

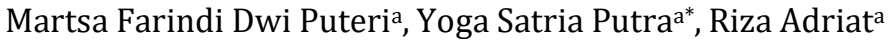

aProdi Geofisika, FMIPA Universitas Tanjungpura

*Email : yogasatriaputra@physics.untan.ac.id

\begin{abstract}
Abstrak
Debit aliran adalah volume air yang masuk ke badan sungai dalam setiap detik. Debit aliran sangat dipengaruhi oleh kecepatan arus dan kedalaman. Debit aliran di suatu perairan dapat digunakan untuk monitoring dan evaluasi sumber air bersih di suatu perairan. Semakin tinggi nilai debit aliran maka kualitas perairan akan semakin baik. Penelitian ini dilakukan untuk mengetahui hubungan kecepatan arus dan kedalaman rata-rata terhadap debit aliran. Nilai kecepatan arus dihitung dengan metode kecepatan arus tiga titik dengan pengambilan data pada kedalaman $0.8 \mathrm{D}, 0.5 \mathrm{D}$, dan $0.2 \mathrm{D}$. Lebar sungai dihitung dengan mengurangkan koordinat akhir dengan koordinat awal lintasan kemudian di konversi ke dalam satuan meter (m). Kedalaman dihitung secara langsung dengan alat ukur sonar. Nilai kecepatan arus, lebar sungai dan kedalaman digunakan untuk menghitung luas penampang lintasan dan debit aliran dengan metode velocity area mid section. Diperoleh hubungan antara kecepatan arus dan kedalaman terhadap debit aliran berdasarkan pola turun naik grafik yang sama pada nilai kecepatan arus, kedalaman dan debit aliran. Korelasi antara nilai kedalaman dan debit aliran diperoleh dengan nilai koefisien korelasi logaritmik sebesar 0.9329 dengan persamaan logaritmik kontinu $y=10426 \ln (x)-15477$. Dari hasil penelitian dapat disimpulkan bahwa debit aliran di Sungai Pawan sangat dipengaruhi oleh besar nilai kecepatan arus dan kedalaman rata-rata pada sungai tersebut.
\end{abstract}

Kata Kunci : Arus, Debit, Kedalaman, Metode Tiga Titik, Metode Velocity Area

\section{Latar Belakang}

Sungai merupakan sumber air yang sangat bermanfaat bagi manusia. Beberapa manfaat sungai bagi kehidupan masyarakat antara lain jalur transportasi, sumber air bersih untuk kegiatan sehari hari seperti mandi mencuci sumber penyedia air minum, dan lain lain. Banyaknya air yang ditampung pada suatu perairan sungai dapat dihitung berdasarkan nilai debit aliran. Debit aliran adalah volume air yang masuk ke badan sungai pada saat pasang dan keluar menuju laut pada saat surut dalam setiap detiknya. Proses keluar masuknya air sungai berada pada muara sungai. Semakin tinggi nilai debit aliran di suatu sungai maka pengaliran air pada sungai tersebut baik dan akan meningkatkan kualitas perairannya.

Besar kecilnya nilai debit aliran akan tergantung pada luas tampang aliran dan kecepatan arus rerata. Luas penampang sangat dipeharuhi oleh nilai kedalaman dan lebar sungai [1]. Penelitian tentang hubungan debit aliran dengan kedalaman pernah dilakukan oleh Neno, et al (2016) yang menyatakan bahwa hubungan debit air dan tinggi muka air di Sungai Lambagu diperoleh suatu hubungan yang sangat kuat (positif) berdasarkan metode logaritmik [2]. Penelitian juga dilakukan oleh Norhadi, et al (2015) yang menyatakan debit aliran rata-rata memiliki pola grafik yang hampir sama artinya adanya hubungan yang kuat antara kedua parameter tersebut [3].
Pada penelitian ini akan diukur kedalaman dan lebar sungai untuk melihat bentuk topografi lintasan penelitian. Hubungan kecepatan arus dan kedalaman terhadap debit aliran di muara Sungai Pawan ditentukan berdasarkan grafik masing-masing parameter. Persamaan logaritmik juga akan dihitung berdasarkan nilai korelasi logaritmik antara debit aliran dengan kedalaman. Persamaan logaritmik tersebut dapat digunakan sebagai persamaan logaritmik kontinu dalam menghitung nilai debit aliran berdasarkan nilai kedalamannya.

\section{Metodologi}

Penelitian ini dilakukan di Sungai Pawan pada titik koordinat lintasan $1^{\circ} 47^{\prime} 52.40^{\prime \prime} \mathrm{S}$ $109^{\circ} 58^{\prime} 50.17^{\prime \prime}$ E sampai dengan $1^{\circ} 47^{\prime} 55.01^{\prime \prime}$ S 109 58'55.29" E dengan peta lokasi lintasan seperti pada Gambar 1. Lintasan dibagi menjadi 13 titik pengambilan data dengan jarak masing-masing titik sebesar $11.5 \mathrm{~m}$. Pengambilan data pada penelitian ini dilakukan selama 7 hari. Data yang diambil adalah data kedalaman, kecepatan arus sungai dan lebar sungai. Titik pengambilan data dapat dilihat pada Gambar 2.

\section{a. Pengambilan data Kedalaman, Lebar, dan Kecepatan arus Sungai}

Pengambilan data kedalaman dilakukan secara langsung pada 13 titik (dapat dilihat pada 
Gambar 1) menggunakan alat ukur sonar. Pengambilan data lebar sungai dilakukan dengan mencatat koordinat awal dan akhir lintasan. Koordinat akhir dikurangi dengan koordinat awal dan dikonversi ke dalam satuan meter (m). Pengambilan data kecepatan arus dilakukan dengan menggunakan metode 3 titik. Metode 3 titik adalah pengukuran kecepatan arus pada 3 kedalaman yang berbeda yaitu $0.8 \mathrm{D}, 0.6 \mathrm{D}$, dan $0.2 \mathrm{D}[2]$

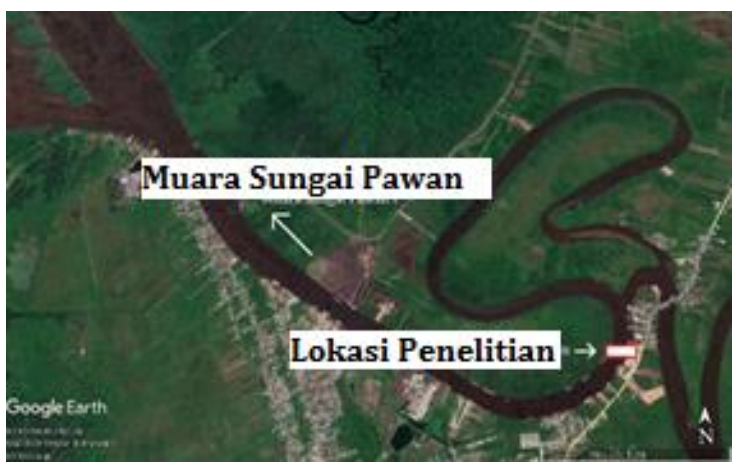

(a)

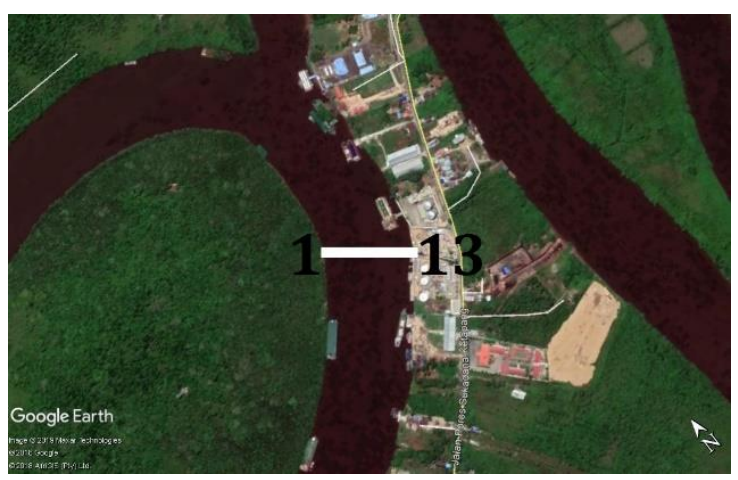

(b)

Gambar 1. (a) Lokasi penelitian dan (b) nomor lintasan penelitian

Pada penelitian ini, kedalaman yang digunakan dalam pengukuran kecepatan arus adalah 0.8D, $0.5 \mathrm{D}$, dan 0.2D. Nilai kecepatan arus tersebut kemudian dirata-ratakan untuk mendapatkan kecepatan arus rata-rata pada satu titik penelitian. Nilai kecepatan arus rata-rata dihitung dengan menggunakan persamaan (1).

$$
u_{x}=\frac{1}{3}(0.2 D+0.5 D+0.8 D)
$$

dengan $u_{x}$ adalah kecepatan arus sungai rata-rata pada titik ke $x(\mathrm{~m} / \mathrm{s}), D$ adalah kedalaman pada titik penelitian (m), 0.2D adalah kecepatan arus sungai pada kedalaman $0.2 \mathrm{D}$ dari permukaan sungai (m), 0,5D adalah kecepatan arus sungai pada kedalaman $0.5 \mathrm{D}$ dari permukaan sungai (m), dan 0.8D adalah kecepatan arus sungai pada kedalaman 0.8D dari permukaan sungai (m) [4]

\section{b. Perhitungan Luas Penampang dan Debit Aliran Sungai}

Nilai debit aliran pada penelitian ini dihitung dengan menggunakan metode velocity area mid section. Pertama-tama data nilai lebar sungai, kedalaman, dan kecepatan arus digunakan untuk menghitung luas penampang pada lintasan penelitian. Penampang melintang pengukuran debit aliran dengan metode velocity area mid section pada lintasan penelitian ditunjukkan oleh Gambar 3. Luas penampang diukur dengan persamaan (2).

$$
a_{x}=\frac{b_{(x+1)}+b_{(x-1)}}{2} d_{x}
$$

dengan $a_{x}$ adalah luas penampang bagian $x\left(\mathrm{~m}^{2}\right)$, $b_{(x+1)}$ adalah jarak titik vertikal sesudah titik vertikal ke $x$ dari titik tetap (m), $b_{(x-1)}$ adalah jarak titik vertikal sebelum titik vertikal ke $x$ dari titik tetap (m), dan $d_{x}$ adalah kedalaman pada titik vertikal ke $x$ [4]. Setelah diperoleh luas penampang, debit aliran masing-masing bagian penampang dihitung berdasarkan persamaan (3). Debit aliran total dihitung menggunakan persamaan (4).

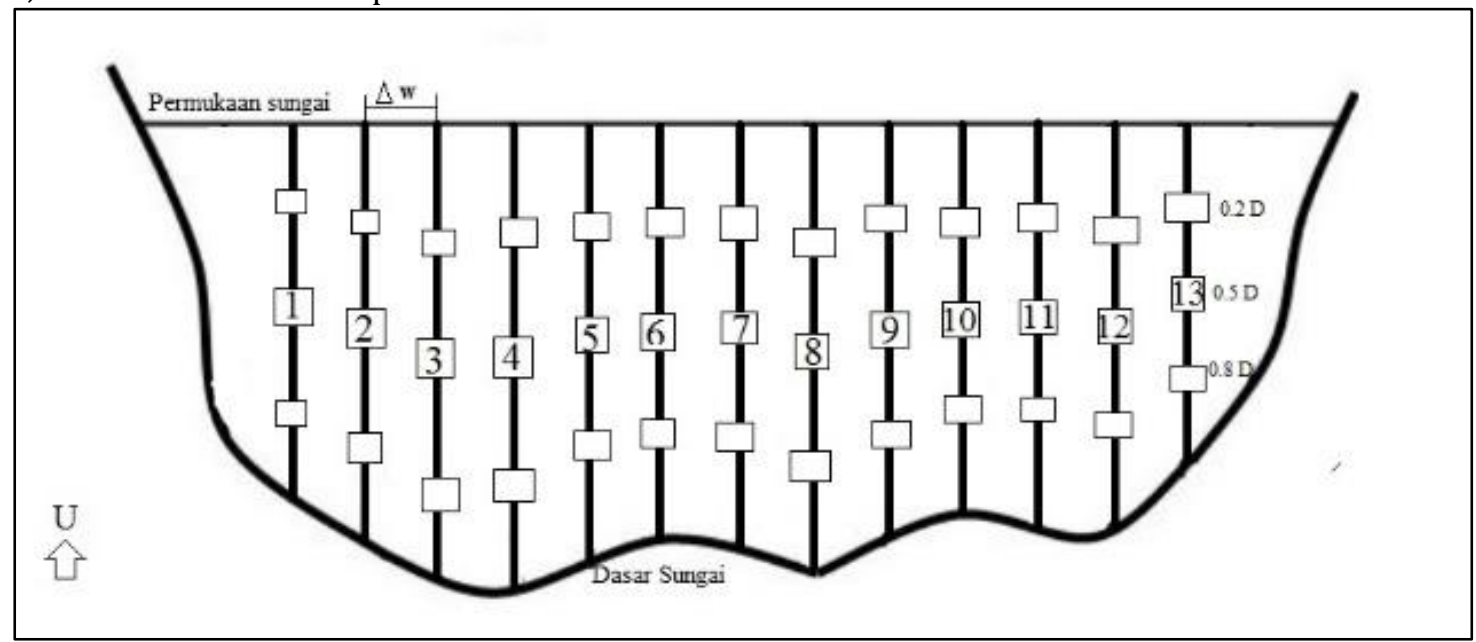

Gambar 2 Titik pengambilan data 


$$
\begin{aligned}
& Q_{X}=u_{x} \cdot a_{x} \\
& Q_{\text {total }}=\sum_{x=0}^{n} Q_{x}
\end{aligned}
$$

dengan $Q_{X}$ adalah debit aliran pada bagian penampang ke $x\left(\mathrm{~m}^{3} / \mathrm{s}\right)$ dan $Q_{\text {total }}$ adalah jumlah seluruh nilai debit aliran pada lintasan penelitian $\left(\mathrm{m}^{3} / \mathrm{s}\right)$.

\section{c. Rating Curve Debit Aliran terhadap Kedalaman}

Nilai debit aliran dan kedalaman kemudian diplot ke dalam grafik korelasi logaritmik untuk menentukan persamaan debit aliran yang kontinu berdasarkan nilai kedalaman sungai. Apabila hasil plot grafik menyerupai rating curve pada Gambar 3 dan memiliki nilai korelasi (R) lebih besar dari 0.5 artinya persamaan logaritma dari rating curve yang dihasilkan dapat dijadikan dasar pengukuran debit yang kotinu pada lintasan penelitian [5].

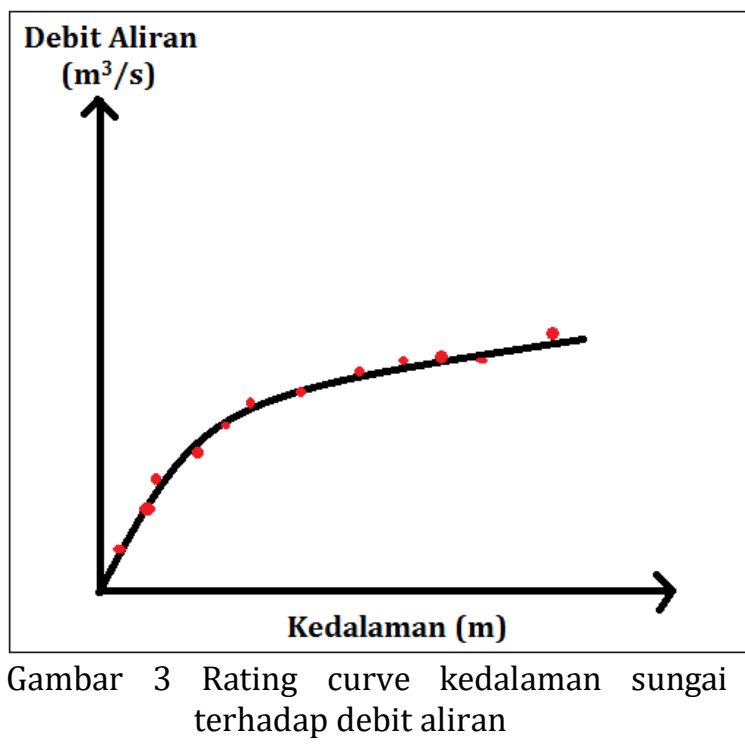

\section{Hasil dan Pembahasan}

\section{a. Topografi dan Kedalaman Sungai}

Setelah dilakukan pengukuran nilai kedalaman dan perhitungan luas penampang, diperoleh sketsa penampang sungai pada lintasan penelitian seperti yang ditunjukkan oleh Gambar 4. Bentuk topografi dasar sungai pada penampang lintasan terlihat semakin ke arah timur semakin dangkal. Hal ini disebabkan oleh lintasan pengambilan data terletak di sungai yang berbentuk cekung seperti yang ditunjukkan oleh Gambar 1(b). Lintasan pada Gambar 1(b) menunjukkan adanya cekungan di lintasan penelitian. Pada daerah cekungan dalam sungai, kemungkinan terjadinya pengendapan sedimen akan semakin besar disebabkan oleh kecepatan arus yang semakin berkurang di daerah tersebut
[6]. Hal ini menyebabkan terjadinya pendangkalan sehingga topografi dasar sungai akan terlihat seperti sketsa pada Gambar 4.

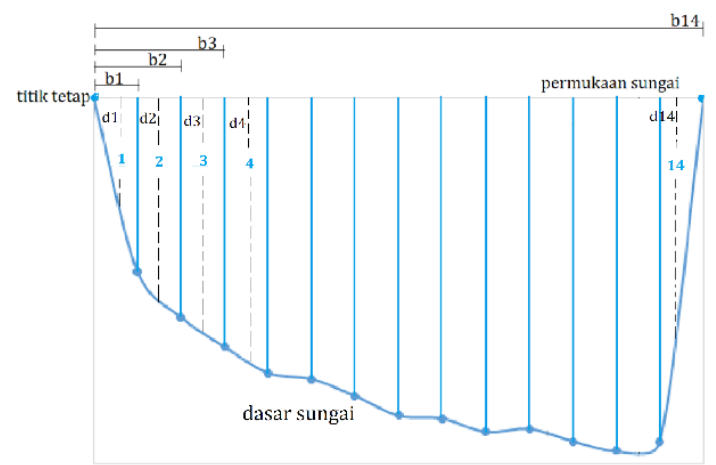

Gambar 4 Sketsa penampang lintasan penelitian

Nilai kedalaman sungai selama 7 hari bervariasi dengan nilai kedalaman terendah sebesar $5.81 \mathrm{~m}$ pada hari ke-4 dan nilai kedalaman tertinggi sebesar 7.13 m pada hari ke 3. Hal ini mungkin disebabkan oleh pengambilan data pada hari ke3 dilakukan pada kondisi surut menuju pasang (pukul 14.00 WIB) sehingga air laut akan mulai memasuki badan sungai dan meningkatkan nilai kedalaman. Nilai rata-rata kedalaman yang diperoleh sebesar $6.23 \mathrm{~m}$ (dapat dilihat pada Gambar 5(b).

\section{b. Kecepatan Arus Sungai Rata-Rata selama 7 Hari}

Nilai kecepatan arus pada Gambar 5(a) menunjukan bahwa nilai kecepatan arus selama 7 hari bervariasi dengan nilai kecepatan arus terendah sebesar $0.444 \mathrm{~m} / \mathrm{s}$ pada hari pertama dan nilai kecepatan arus tertinggi sebesar 0.552 $\mathrm{m} / \mathrm{s}$ pada hari ke-5. Nilai rata-rata kecepatan arus yang diperoleh sebesar $0.494 \mathrm{~m} / \mathrm{s}$. Berdasarkan nilai kecepatan arus, aliran pada lintasan penelitian yang menuju muara Sungai Pawan termasuk klasifikasi sungai berarus sedang. Sungai berarus sedang memiliki kecepatan arus berkisar $25 \mathrm{~cm}$ sampai dengan 50 $\mathrm{cm}(0.25-0.5 \mathrm{~m} / \mathrm{s})$ dalam setiap detiknya [7].

\section{c. Debit Aliran Rata-Rata selama 7 Hari}

Gambar 5 (c) menunjukkan bahwa nilai debit aliran selama 7 hari bervariasi. Debit aliran terendah memiliki nilai sebesar $2525.99 \mathrm{~m}^{3} / \mathrm{s}$ pada hari ke-4, hal ini disebabkan oleh nilai kecepatan arus dan kedalaman yang mengalami penurunan pada hari ke-2. Debit aliran tertinggi memiliki nilai sebesar $4720.14 \mathrm{~m}^{3} / \mathrm{s}$ pada hari ke-3, hal ini juga disebabkan oleh adanya penurunan nilai kecepatan arus dan kedalaman. Nilai rata-rata debit aliran yang diperoleh sebesar $3571.03 \mathrm{~m}^{3} / \mathrm{s}$. Perubahan nilai debit pada setiap harinya tidak menunjukkan perubahan yang signifikan. 


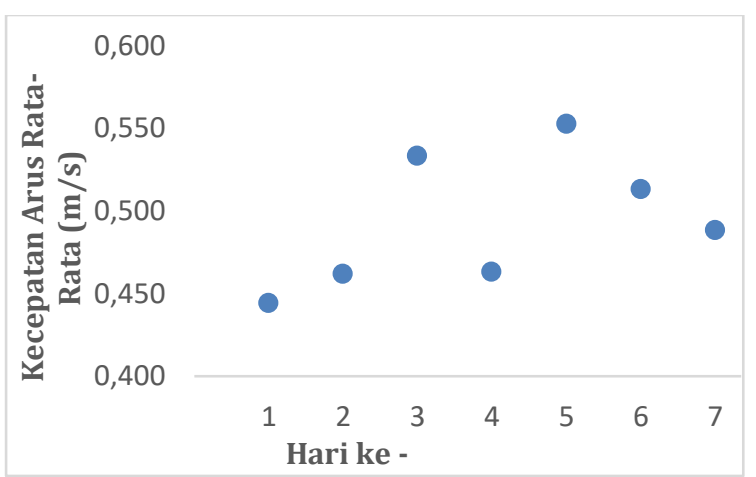

(a)

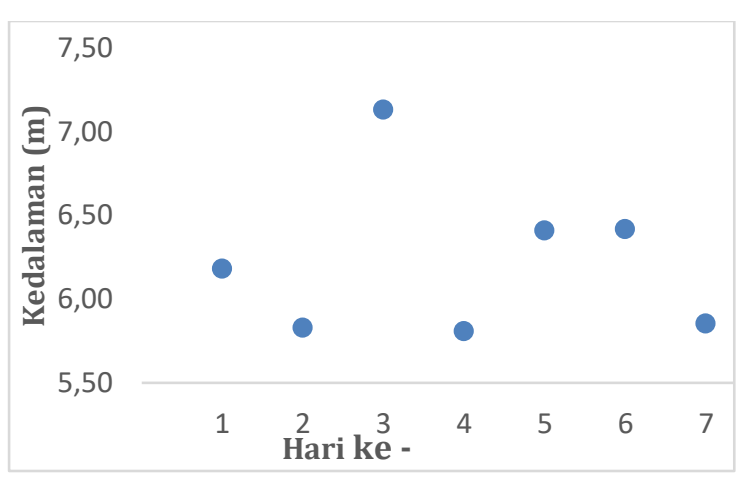

(b)

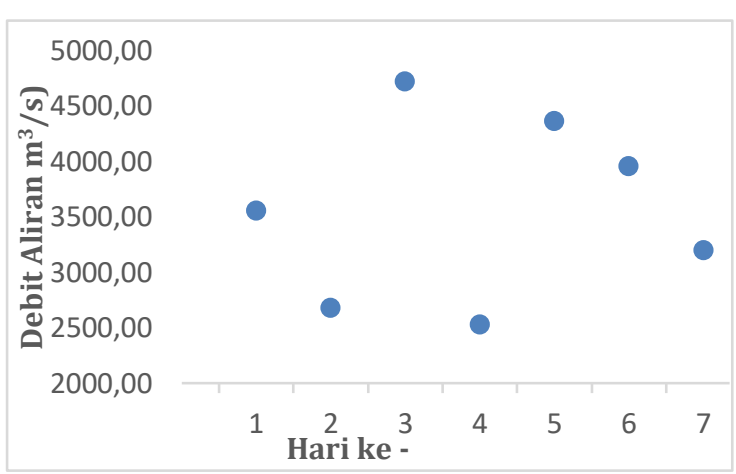

(c)

Gambar 5 Grafik (a) kecepatan arus, (b) kedalaman, dan (c) debit aliran terhadap hari penelitian

\section{d. Analisis Aliran Sungai}

Pola turun naiknya grafik kecepatan arus, kedalaman dan debit aliran hampir sama. Perbedaan pola grafik hanya terlihat pada hari ke-2. Nilai kecepatan arus pada hari ke-2 mengalami kenaikan sebesar $0.018 \mathrm{~m} / \mathrm{s}$ sedangkan nilai kedalaman mengalami penurunan nilai sebesar $0.35 \mathrm{~m}$. Kecepatan arus akan meningkat sesuai dengan makin berkurangnya kedalaman perairan dan akhirnya angin menjadi tak berpengaruh sama sekali terhadap kecepatan arus [8]. Nilai debit aliran pada hari ke-2 mengalami penurunan sebesar $878.88 \mathrm{~m}^{3} / \mathrm{s}$ yang mungkin disebabkan oleh nilai kedalaman yang juga menurun. Kenaikan pada nilai kecepatan arus pada hari ke-2 juga tidak terlalu besar, sehingga, dari pola turun naiknya grafik pada Gambar 5, dapat disimpulkan bahwa nilai kecepatan arus, kedalaman sungai dan debit aliran sangat berhubungan kuat satu sama lain.

Korelasi antara nilai kecepatan aliran dan debit aliran diperoleh dengan nilai koefisien korelasi sebesar 0.80944 yang artinya saling berhubungan sangat kuat. Korelasi antara kedalaman dan debit aliran diperoleh dengan nilai koefisien korelasi sebesar 0.9329 dengan persamaan logaritmik $y=10426 \ln (x)-15477$. Grafik kurva logaritmik pada Gambar 7 tidak menunjukkan bentuk yang sama dengan grafik rating curve pada Gambar 3 tetapi nilai korelasi (R) grafik pada Gambar 7 lebih besar dari 0.5 artinya persamaan logaritmik pada grafik tersebut dapat dijadikan dasar pengukuran debit yang kotinu pada lintasan penelitian.

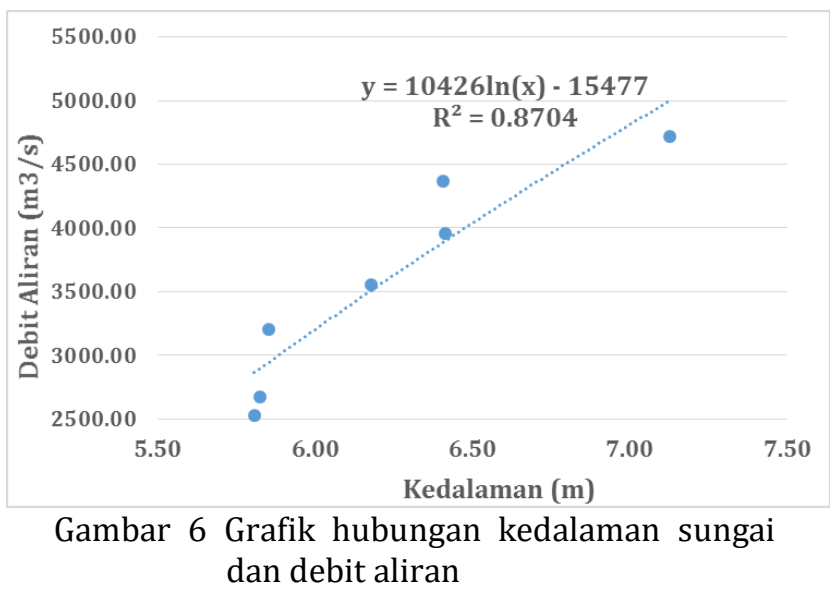

\section{Kesimpulan}

Dari hasil penelitian ini, diperoleh bentuk topografi dasar lintasan penelitian semakin kearah timur akan semakin dangkal. Kecepatan arus sangat mempengaruhi debit aliran di Sungai Pawan dengan nilai rata-rata debit aliran sebesar $3571.03 \mathrm{~m}^{3} / \mathrm{s}$. Korelasi kecepatan arus terhadap debit aliran sebesar 0.8099. Korelasi kedalaman terhadap debit aliran sebesar 0.9329 dengan persamaan logaritmik $y=10426 \ln (x)-15477$ yang dapat digunakan sebagai persamaan logaritmik kontinu dalam perhitungan nilai debit aliran pada lintasan penelitian.

\section{Daftar Pustaka}

[1]Elisa, Pengukuran dan Perkiraan Debit Sungai. Diakses dari http://elisa.ugm.ac.id, 2011. [Diakses pada 12 Desember 2019].

[2] Neno, A. K.; Harijanto, H.; Wahid, A., Hubungan Debit Air Dan Tinggi Muka Air Di Sungai Lambagu Kecamatan Tawaeli Kota Palu, Warta Rimba, Fakultas Kehutanan, Universitas Tadulako, 4(2), 1-8, 2016. 
[3] Norhadi, A.; Marzuki, A.; Wicaksono, L.; Yacob, R. A., Studi Debit Aliran Pada Sungai Antasan Kelurahan Sungai Andai Banjarmasin Utara, Poros Teknik, Politeknik Negeri Banjarmasin, 7(1), 1-53, 2015.

[4] SNI 8066, Tata Cara Pengukuran Debit Aliran Sungai dan Saluran Terbuka Menggunakan alat ukur arus dan Pelampung, Badan Standar Nasional (BSN), Jakarta, 2015.

[5] Hallerth, J., dan Bydén, L. C., Discharge and Sediment Transport in The Kapuas River, Faculty of Engineering at Lund University, Sweden, (Minor Field Study), 2013.

[6] Leopold, L.B., Wolman, M.G., River Channel Patterns; Braided. Meandering and Straight. Prof. Pap. 282-B. U.S. Geological Survey, Washington, DC, 1957.

[7] Supartiwi, E. N., Karakteristik Komunitas Fitoplankton dan Perifiton Sebagai Indikator Kualitas Lingkungan Sungai Ciujung Jawa Barat, Institut Pertanian Bogor, Bogor, 2000, (Skripsi)

[8]Hutabarat, S., dan Evans, S. M., Pengantar Oseanografi, Universitas Indonesia Press, Jakarta, 1986. 